ВІСНИК

ОДЕСЬКОГО НАЦІОНАЛЬНОГО

МОРСЬКОГО УНІВЕРСИТЕТУ

№ 2 (62), 2020
HERALD

OF THE ODESSA NATIONAL

MARITIME UNIVERSITY № 2 (62), 2020

УДК 629.5.01:629.584

DOI 10.47049/2226-1893-2020-2-90-105

\title{
УДОСКОНАЛЕННЯ МЕТОДУ РОЗРАХУНКУ \\ МШЦНОСТ КОРПУСУ ПІДВОДНОГО АПАРАТУ ТОРОЇДАЛЬНОЇ ФОРМИ, ВИГОТОВЛЕНОГО НАМОТУВАННЯМ
}

\author{
Є.T. Бурдун \\ к.т.н. завідувач кафедри \\ «Проектування та виробництва конструкцій із композиційних матеріалів» \\ С.Ф. Присташ \\ аспірантка кафедри \\ «Проектування та виробництво конструкцій із композиційних матеріалів»
}

Наџіональний університет кораблебудування ім. адм. Макарова

Анотація. В статті досліджується задача напружено-деформованого стану і оцінки міцності порожнистої замкненої тороїдальної оболонки, яка виконана з полімерного композиційного матеріалу способом намотування.

Удосконалено метод розрахунку напружено-деформованого стану $i$ оцінки міцності при гідростатичному стисканні міцного корпусу підводного апарату тороїдальної форми з урахуванням конструктивно-технологічних факторів виготовлення способом намотування волокном (стрічкою) із полімерних композиційних матеріалі та рекомендацій класифікаційного товариства Bигеаи Veritas, щуодо оцінки пружних характеристик композиційного матеріалу по властивостям його компонентів.

Отримано закономірності впливу на напружено-деформований стан намотаного тороїдального міиного корпусу схем армування, геометричних параметрів корпусу, перспективних типів армуючих наповнювачів та сполучників, змінної товщчини та ї̈ осереднення. Встановлено, щуо не врахування конструктивно-технологічних факторів виготовлення способом намотування та особливостей розрахунку композиційних матеріалів і використання спрощених методів розрахунку призводить до зменшення напружень в два рази та виникненню помилки в небезпечну сторону. Обмеження по міцності прийняті у вигляді комбінованого критерія Цая-Ву-Гофмана.

Проведено оцінку техніко-економічної ефективності використання високоміцних волокнистих матеріалів для тороїдальних міцних корпусів при обмеженні по міцності з метою створення раціональних в ваговому та технологічному відношенні корпусів в залежності від глибини експлуатації на початковій стадії проектування апаратів. Встановлено, щзо для міцних корпусів підводних апаратів тороїдальної форми найбільше підходять епоксипластики на основі середніх по модулю та високоміцних вуглецевих волокон.

Ключові слова: тороїдальний міцний корпус, напружено-деформований стан, гідростатичний тиск, склопластик, вуглепластик, намотування.

(С) Бурдун Є.Т., Присташ С.Ф., 2020 
ВІСНИК

ОДЕСЬКОГО НАЦІОНАЛЬНОГО

МОРСЬКОГО УНІВЕРСИТЕТУ

№ 2 (62), 2020
HERALD

OF THE ODESSA NATIONAL

MARITIME UNIVERSITY № 2 (62), 2020

УДК 629.5.01: 629.584

DOI 10.47049/2226-1893-2020-2-90-105

УСОВЕРШЕНСТВОВАНИЕ МЕТОДА РАСЧЕТА

ПРОЧНОСТИ КОРПУСА ПОДВОДНОГО АППАРАТА ТОРОИДАЛЬНОЙ ФОРМЫ, ВЫПОЛНЕННОГО НАМОТКОЙ

\section{Е.Т. Бурдун}

к.т.н. заведующий кафедрой

«Проектирования и производства конструкций из композиционных материалов»

\section{С.Ф. Присташ}

аспирантка кафедры

«Проектирования и производства конструкций из композиционных материалов»

Национальный университет кораблестроения им. адм. Макарова

Аннотация. В статье исследуется задача напряженно-деформированного состояния и оценки прочности полой замкнутой тороидальной оболочки, которая выполнена из полимерного композиционного материала методом намотки.

Усовершенствован метод расчета напряженно-деформированного состояния и оченки прочности при гидростатическом сжатии прочного корпуса подводного аппарата тороидальной формы с учетом конструктивно-технологических факторов изготовления способом намотки волокном (лентой) из полимерных композиционных материалов и рекомендаџий классификационного общества Bureaи Veritas, по оченке упругих характеристик композиционного материала по свойствам его компонентов.

Получены закономерности влияния на напряженно-деформированное состояние намотанного тороидального прочного корпуса схем армирования, геометрических параметров корпуса, перспективных типов армируюших наполнителей и связующего, переменной толщины и ее осреднения. Установлено, что не учет конструктивно-технологических факторов изготовления способом намотки и особенностей расчета композиционных материалов, а также использование упрощенных методов расчета приводит к уменьшению напряжений в два раза и возникновению ошибки в опасную сторону. Ограничения по прочности приняты в виде комбинированного критерия Цая-Ву-Гофмана.

Проведена оценка технико-экономической эффективности использования высокопрочных волокнистых материалов для тороидальных прочных корпусов при ограничении по прочности с иелью создания рачиональных в весовом и технологическом отношении корпусов в зависимости от глубинь эксплуатации на начальной стадии проектирования аппаратов. Установлено, что для прочных корпусов подводных аппаратов тороидальной формы больше подходят эпоксипластики на основе средних по модулю и высокопрочных углеродных волокон. 
Ключевые слова: тороидальный прочный корпус, напряженнодеформированное состояние, гидростатическое давление, стеклопластик, углепластик, намотка.

UDC 629.5.01: 629.584

DOI 10.47049/2226-1893-2020-2-90-105

\title{
IMPROVEMENT OF THE METHOD OF CALCULATION OF STRENGTH OF THE PRESSURE HULL OF THE UNDERWATER APPARATUS OF THE TOROIDAL FORM, MADE BY WINDING
}

\author{
E. Burdun \\ Ph.D. Head of the Department \\ «Design and manufacture of structures from composite materials»

\section{S. Prystash} \\ Postgraduate of the Department \\ «Design and production of structures from composite materials» \\ National University of Shipbuilding named after adm. Makarova
}

Abstract. The problem of stress-strain state and evaluation of the strength of a hollow closed toroidal shell, which is made of a polymer composite material by winding, is investigated in the article.

The method of calculating the stress-strain state and assessing the strength of hydrostatic compression of the strong body of a toroidal submarine has been improved, taking into account structural and technological factors of manufacturing by fiber winding (tape) of polymer composite materials and recommendations of the Bureau Veritas classification society on the evaluation of elastic characteristics properties of its components.

Regularities of influence on the stress-strain state of the wound toroidal strong body of reinforcement schemes, geometrical parameters of the body, perspective types of reinforcing fillers and connectors, variable thickness and its averaging are obtained. It is established that failure to take into account the structural and technological factors of the method of winding and the peculiarities of the calculation of composite materials and the use of simplified calculation methods leads to a reduction of stresses twice and an error in the dangerous direction. Strength constraints are accepted in the form of a combined Tsai-Wu or Hoffman test.

The evaluation of technical and economic efficiency of high-strength fibrous materials for toroidal durable housings with strength limitations in order to create rational in weight and technological terms housings depending on the depth of operation at the initial stage of device design. It is established that epoxyplastics based on medium modulus and high-strength carbon fibers are the most suitable for strong hulls of toroidal submarines.

Keywords: toroidal strong case, stress-strain state, hydrostatic pressure, fiberglass, carbon fiber, winding. 
Вступ. Методом намотування можна отримати замкнену тороїдальну оболонку з геометрично формою близькою до ідеальної, це надає міцним корпусам підводних технічних засобів переваги перед аналогами 3 металевих сплавів по відносній (ефективній) масі міцного корпусу та за умовами міцності і стійкості.

На сьогодні роботи по тороїдальним оболонкам, як несучим оболонкам міцних корпусів підводних апаратів, описують лише як варіанти оригінальних архітектурно-конструктивних компоновок зовнішнього виду підводних апаратів та конструкцій з міцними корпусами в формі тору, або сконцентровані на дослідженні напружено-деформованого стану (НДС) та стійкості ізотропних або ортотропних тороїдальних оболонок, навантажених зовнішнім рівномірним тиском. Використання полімерних композиційних матеріалів (ПКМ) потребує нового підходу до проектування несучої оболонки міцного корпусу в формі замкненого тору 3 урахуванням конструктивно-технологічних особливостей при виготовленні ії способом намотування.

Питання з оцінки міцності корпусу тороїдальної форми зі змінною по меридіану товщиною, в залежності від геометрії тору, схеми армування, кута спірального намотування, мінімальної товщини оболонки корпусу та інших факторів залишаються невирішеними на шляху просування тора в підводне суднобудування.

Мета статті - удосконалення методу розрахунку міцності корпусу підводного апарату тороїдальної форми, виготовленого намотуванням волокном із полімерних композиційних матеріалів.

Основний матеріал. Розглянуто відпрацьовані технологічні схеми виготовлення кругових замкнутих тороїдальних оболонок способом намотування волокном (стрічкою): поперечне намотування в комбінації з повздовжнім намотуванням (або викладкою) (рис.1 а) та спіральне намотування (рис.1 б).

При розв'язанні задачі використано результати порівняльного аналізу методів оцінки ефективних пружних характеристик композиційного матеріалу по вихідним характеристикам його компонентів та їх об'ємному складу проводився для вуглепластика (ВП) та склопластика (СП) при різних схемах намотування вздовж ліній головних кривизн замкненої тороїдальної оболонки [1]. Аналіз здійснювався на основі побудованої дискретної моделі, що враховує закони розподілу товщин шарів уздовж меридіана при поперечному намотуванні в комбінації 3 повздовжнім намотуванням (або викладкою) і спіральним намотуванням, описаних М.А. Комковим при дослідженні конструктивно-технологічних особливостей намотування тороїдальних балонів тиску кругового поперечного перерізу. При намотуванні замкнутих тороїдів формується стінка змінної товщини уздовж меридіана 3 шаруватою ортотропною структурою ПКМ. При цьому товщина стінки тороїда уздовж меридіанного перерізу збільшується від зовнішнього екватора до внутрішнього. 


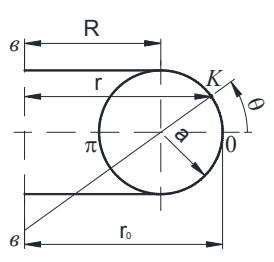

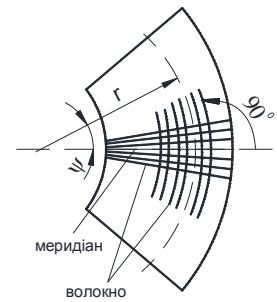

a)

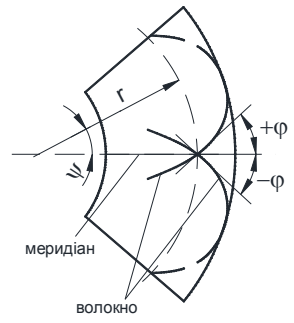

б)

Рис. 1. Геометричні розміри та схеми намотування кругової тороїдальної оболонки виконаної: а) поперечним намотуванням в комбінації з поздовжнім намотуванням (або викладкою); б) спіральним намотуванням:

$a$ - радіус серединної поверхні перерізу меридіана;

$R$ - відстань від вісі обертання в-в до изентру меридіанного перерізу $O$;

$r(\theta)$ - відстань від вісі обертання в-в до деякої точки $K(\theta)$ серединної поверхні у меридіанному перерізі;

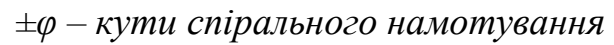

Міцний корпус представлено замкненою шаруватою ортотропною тороїдальною оболонкою кругового поперечного перерізу з шарами змінної товщини. Така постановка задачі вперше враховує конструктивно-технологічні можливості реалізації схем армування.

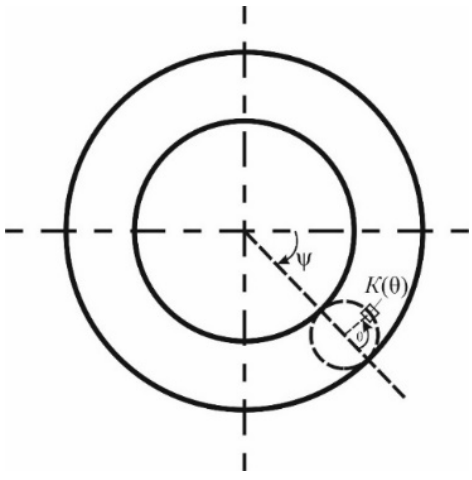

a)

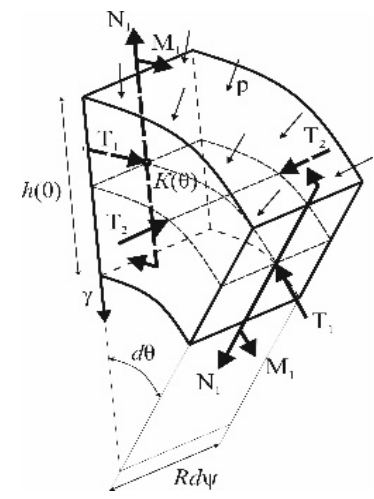

б)

Рис. 2. Геометричні параметри діаметрального перерізу тороїдальної оболонки змінної товщини (а) та погонні зусилля в точиі типу $K(\theta)$, серединної поверхні оболонки (б) 
Напружено-деформований стан тонкостінної замкненої тороїдальної оболонки змінної товщини під дією рівномірно розподіленого зовнішнього тиску $p$ розглядається як вісесиметрична напівбезмоментна задача (по координаті $\psi$ ). Система рівнянь рівноваги елемента та ii рішення методом Бубнова-Гальоркіна для вісесиметричної задачі (рис. 2, б) ортотропної тороїдальної оболонки у точці $K(\theta)$ серединної поверхні отримано в [2;3] та має вигляд

$$
\left\{\begin{array}{l}
\frac{\partial B T_{1}}{\partial \theta}-\frac{\partial B}{\partial \theta}+A B k_{1} N_{1}=0 \\
-\left(k_{1} T_{1}+k_{2} T_{2}\right)+\frac{1}{A B} \frac{\partial B N_{1}}{\partial \theta}=p
\end{array}\right.
$$

де $A=a$ і $B=a / k(1+k \cos \theta)-$ коефіцієнти Ламе для тороїдальної поверхні; $k=a / R-$ геометричний параметр форми тора;

$k_{1}, k_{2}$ - головні кривизни;

$N_{l}, T_{1}, T_{2}$ - погонні зусилля;

індекси 1 і 2 відповідають двом криволінійним координатам $\theta$ і $\psi$, відповідно.

Збіжність отриманих рішень аналізувалась при утриманні по $m$ кінцевого числа членів ряду $M=0,1, \ldots, 9$ [4]. Для прогинів $w(\theta)$ ортотропної тороїдальної оболонки змінної товщини достатньо утримувати $M=3$ члени ряду; для нормальних зусиль $T_{1}$ та $T_{2}$ достатньо утримувати $M=3$ члени ряду; для згинаючого моменту $M_{1}$ та перерізуючої сили $N_{1}$ достатньо утримувати $M=4$ та $M=5$ члени ряду відповідно. Для розрахунку НДС намотаного тороїдального міцного корпусу, що знаходиться під дією зовнішнього гідростатичного тиску прийнято утримувати $M=5$ членів ряду.

Для підтвердження адекватності запропонованого методу його було апробовано на рішеннях [5] для ізотропної тороїдальної оболонки постійної товщини при $k=0,25$. Результати отримані в цій роботі практично співпали з [5], що свідчить про адекватність запропонованої моделі для визначення компонентів напружено-деформованого стану. Також при $k=0(R \rightarrow \infty)$ результат співпадає 3 рішенням для нескінченної ортотропної циліндричної оболонки (кільця) [6].

Оцінку міцності проведено за комбінованим енергетичним критерієм Цай-Ву-Гофмана для плоского напруженого стану згідно практичних рекомендацій класифікаційного співтовариства Bureau Veritas для суден із ПКМ. Мінімальний припустимий коефіцієнт безпеки для тороїдального міцного корпусу підводного апарату складається 3 коефіцієнтів, які враховують особливості ПКМ та становить $\mathrm{CF}=2,59$ [7]. 
Дослідження впливу геометричних параметрів тору, схем армування та перспективних типів армуючого наповнювача i сполучника в варіантах з урахуванням змінної товщини стінки та іiї осередненням по меридіану показано на графіках найбільш значних сумарних напруженнях $\sigma_{\theta}\left(M_{1}, T_{1}\right)$ (далі $\left.\sigma_{\theta}\right)$ при гідростатичному стисканні $\left(0 \leq k \leq 0,3, \delta=\left(l_{1}+l_{2}\right) / l_{1}\right)$. Встановлено, що при збільшенні кількості поперечних шарів по відношенню до повздовжніх в 2 рази величина напружень $\sigma_{\theta}$ зменшується на $14 \%$ для ВП (рис. 3 ) та 12,6 \% для СП.

1

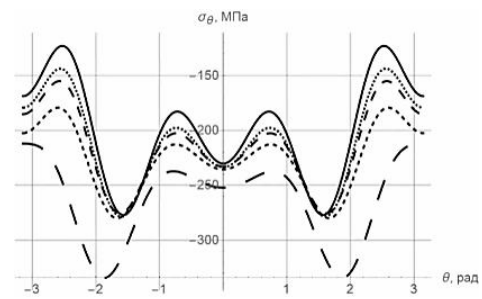

1

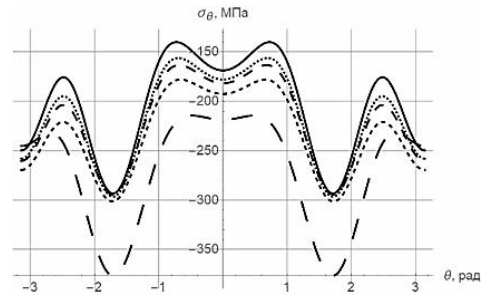

2

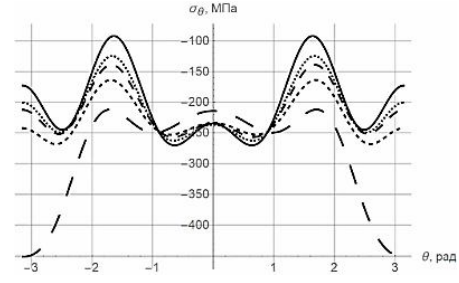

a)

2

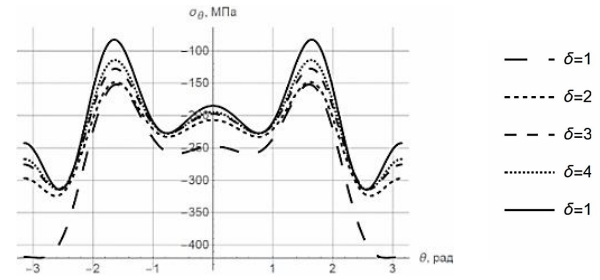

б)

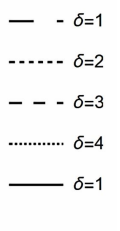

$-\delta=1$ $\delta=2$ $--\delta=3$

Рис. 3. Епюри розподілу напружень $\sigma_{\theta}$ для намотаних тороїдальних мійних корпусів $\left(a=1 \mathrm{M}, k=1 / 3, \Delta_{m}=0,04\right)$ зі структурою ПКМ $\left(0 \% 90^{\circ}\right)$ на зовнішній (1) та внутрішній (2) поверхнях на глибині $H_{S W}=1000$ м для вуглепластика M35J/Ероху: змінної̈ товщини (а), осередненої товщини (б)

Порівняльна оцінка розробленого методу розрахунку напруженодеформованого стану міцного корпусу підводного апарату тороїдальної форми при гідростатичному стисканні 3 урахуванням конструктивнотехнологічних факторів виготовлення його способом намотування волокном із ПКМ на основі розрахункової моделі для поперечного намотування в комбінації з повздовжньою намоткою зі змінною товщиною уздовж меридіана (рис. 3, а) з методом розрахунку, що враховує постійну товщину стінки (рис. 3, б). Заміна розрахунку тороїдальної оболонки з шарами змінної товщини на оболонку 3 осередненою товщиною шарів уздовж поперечного перерізу призводить до зниження максимальних напружень $\sigma_{\theta}$ на $8 \%$ по зовнішній поверхні, та на $13 \%$ по внутрішній поверхні. Максимальні напруження $\sigma_{\theta}$ для обох методів знаходяться на 
внутрішній поверхні тороїдальної оболонки. Небезпечні точки при змінній товщині знаходяться в районі кутів $\theta=\pi / 6$ та $\theta=5 \pi / 6$, при осередненій товщині в районі кута $\theta=5 \pi / 6$.

Порівняємо розподіл прогинів $w(\theta)$ для тороїдальних міцних корпусів із СП та ВП (виконаних поперечним намотуванням в комбінації 3 повздовжнім намотуванням) 3 традиційно застосовуваними нині металами (міцні корпуси розраховувались як ізотропні оболонки змінної товщини в меридіанному перерізі) для міцних корпусів, таких як, високоміцна сталь (АК-25), титанові сплави (марки ВТ) і алюмінієві сплави (марки В95). Аналіз рис. 4 показав, що тороїдальний міцний корпус із ВП на основі надвисокомодульних волокон $\left(\mathrm{E}_{\mathrm{B}}=860\right.$ ГПа) майже не поступається сталі та титановим сплавам. При цьому густина ВП в 4,3 рази менша за густину сталі і в 2,5 рази менша за густину титанового сплаву. Цей факт робить намотаний тороїдальний МК більш легким та технологічним в порівнянні з традиційними матеріалами та ефективним за позитивною плавучістю. Тому тороїдальний міцний корпус виготовлений методом намотування із ПКМ має істотні переваги перед аналогічним міцним корпусом із металу.

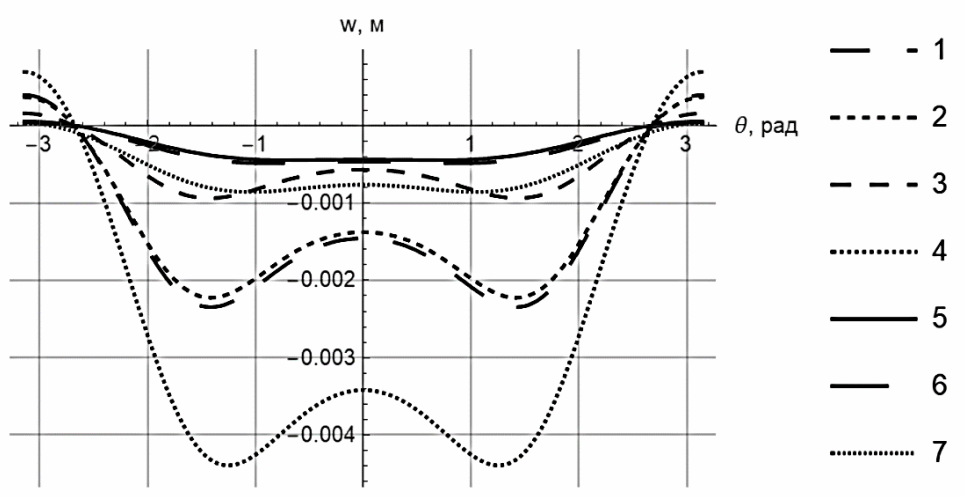

Рис. 4. Розподіл прогинів $w(\theta)$ для тороїдальних міщчних корпусів із СП,

ВП та традиційних конструкційних матеріалів, виконаних поперечним намотуванням в комбіначї̈ з повздовжнім намотуванням (або викладкою) при $\Delta_{m}=0,1 ; k=1 / 3 ; H_{S W}=1000$ м: 1 - ВП МЗ5J/ЕДТ-10; 2 - ВП ІМ10/ЕДТ-10; 3 - ВП CN-90/ЕДТ-10; 4 - СП ВМПС/ЕДТ-10; 5 - сталь АК-25; 6 - титановий сплав ВТ; 7 - алюмінієвий сплав В95

Порівняльна оцінка розробленого методу розрахунку напруженодеформованого стану міцного корпусу підводного апарату тороїдальної форми при гідростатичному стисканні з урахуванням конструктивно-технологічних факторів виготовлення його способом намотування волокном 
із ПКМ на основі розрахункової моделі зі змінною товщиною уздовж меридіана зі спрощеним методом розрахунку, що базується на теоретичній оцінці пружних характеристик та використовує безмоментне рішення Фепля [8]. На прикладі ВП (рис. 5) показано, що використання спрощеного методу призводить до заниження величин напружень.

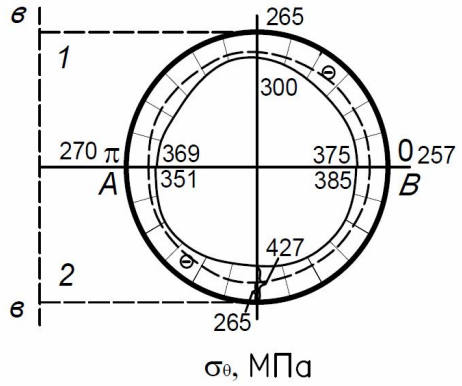

a)

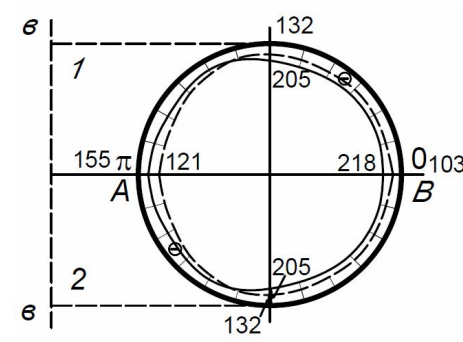

$\sigma_{\psi}, \mathrm{M} \Pi \mathrm{a}$

б)

Рис. 5. Епюри напружень $\sigma_{\theta}(a)$ i $\sigma_{\psi}($ () для тороїдального корпусу $(k=1 / 3)$ товщиною, що задовольняс умові стійкості по верхньому критичному тиску виготовленого поперечним намотуванням в комбінації із повздовжньою намоткою на внутрішній (1) $i$ зовнішній (2) поверхнях на глибині $H_{S W}=1000$ м для ВП МЗ5J/ЕДТ-10:

- - удосконалений метод; --- - спрощений метод

При використанні удосконаленого методу величини напружень будуть максимальними на внутрішній поверхні, а для спрощеного методу вони будуть однакові для обох поверхонь. Так, при $\theta=0 \sigma_{\theta}$ в першому випадку вища на $30 \%$, при $\theta=\pi / 2$ вища на $37 \%$, при $\theta=\pi$ вища на $27 \%$, а для $\sigma_{\psi}$ при при $\theta=0$ вища на $52 \%$, при $\theta=\pi / 2$ вища на $36 \%$, при $\theta=\pi$ нижча на $22 \%$. Така велика розбіжність призводить до виникнення помилки в небезпечну сторону.

Результати оцінки ефективності міцного корпусу тороїдальної форми, виготовленого способом намотування із ПКМ за наступними критеріями: 1) відношення маси міцного корпусу $m_{M \kappa}$ до його водотоннажності $m_{w}$, що забезпечує плавучість апарату і $є$ основним критерієм якості міцного корпусу, та має бути найменшим; 2) вартість міцного корпусу.

Співвідношення маси тороїдального міцного корпусу $m_{M \kappa}$ до його водотоннажності $m_{w}[9]$

$$
\frac{m_{M K}}{m_{w}}=2 \frac{a h_{m}}{\left(a+\frac{\left.h_{m} / 2\right)^{2}}{\rho_{w}}\right.}
$$


де $\rho$ - густина матеріалу корпусу, кг/ $\mathrm{m}^{3}$;

$\rho_{\mathrm{w}}$ - густина морської води $\left(\rho_{\mathrm{w}}=1027 \mathrm{\kappa} / \mathrm{m}^{3}\right)$;

$h_{m}$ - осереднена по меридіану тороїдального корпусу товщина $h(\theta, k)$.

Досліджено вплив фізико-механічних властивостей традиційних металів для монолітних міцних корпусів підводних апаратів, таких як: сталь (АК-25), титанові сплави (марки ВТ), алюмінієві сплави (марки В95) та СП і ВП, отриманих поперечним намотуванням в комбінації 3 повздовжнім намотуванням, на показник $m_{M K} / m_{w}$ міцних корпусів тороїдальної форми кругового поперечного перерізу з $k=0,33$ (рис. 6). Маса корпусу визначається згідно до удосконаленого методу за умовою міцності та стійкості [10].

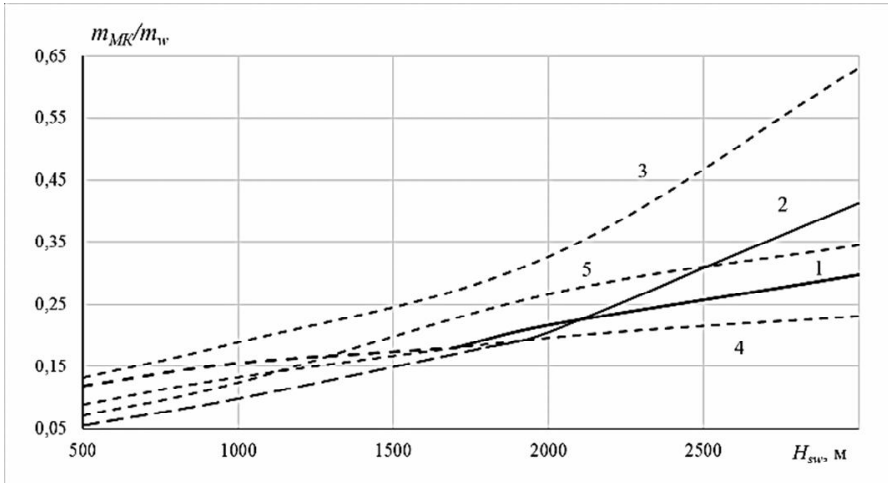

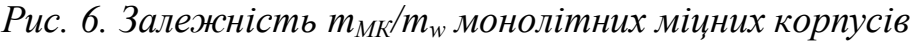
тороїдальної форми $(k=1 / 3)$ із різних конструкиійних матеріалів від робочої глибини занурення і умови міџності: 1 - УП МЗ5J/ЕДТ-10; 2 - CП GLASS/ЕДT-10; 3 - сталь (АК-25); 4 - алюмінісві сплави (В95);

$$
\begin{gathered}
5 \text { - титанові сплави (BT) } \\
\text {--- - умова стійкості; - - умова міцності }
\end{gathered}
$$

Із аналізу рис. 6 видно, що при розрахунку СП та ВП міцних корпусів на малих глибинах (до 1750 м) визначальним $€$ позиція стійкості, a для великих глибин визначальним є позиція міцності. Для розрахунку традиційних матеріалів, в даному прикладі, визначальним $є$ позиція стійкості.

Встановлено, що для міцних корпусів, виконаних поперечним намотуванням в комбінації із повздовжнім намотуванням співвідношення $m_{M \kappa} / m_{w}$ збільшується, на відміну від визначення даного співвідношення за умовою стійкості.

На основі достатньої умови переваги вибору високоміцних матеріалів для міцних корпусів підводних апаратів без детального опрацювання всього проекту, розробленого В.М. Грековим [11], дана оцінка 
техніко-економічної ефективності використання різних матеріалів для міцного корпусу тороїдальної форми з урахуванням їх вартості та жорсткості (рис. 7) при обмежені по міцності та стійкості.

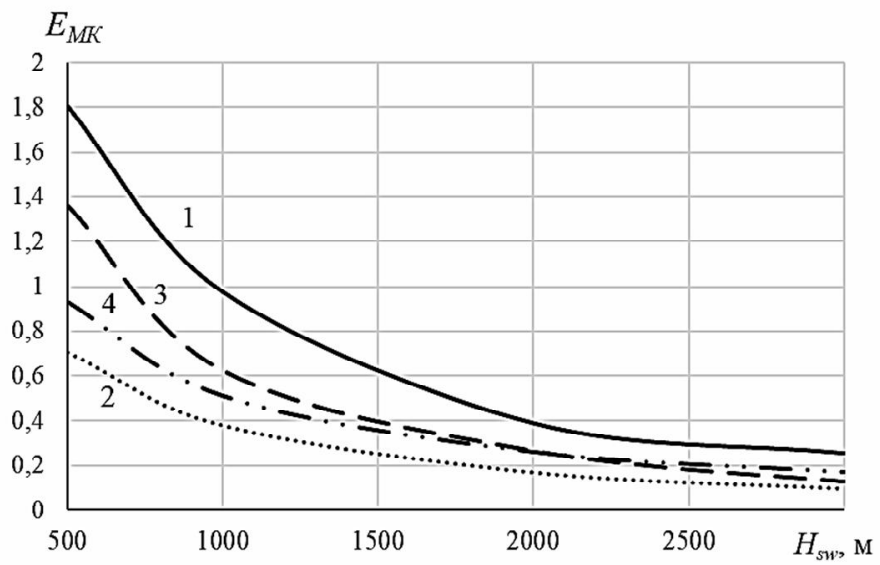

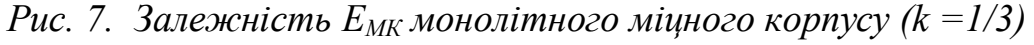
тороїдальної форми змінної товщчини із різних конструкційних матеріалів від робочої глибини занурення: 1 - СП ВМПС/ЕДТ-10;

2 - ВП МЗ5J/ЕДТ-10; 3 - сталь $\left(\sigma_{0,2}=800-900\right.$ МПа); 4 - титанові сплави (BT)

Ефективність використання різних матеріалів для міцного корпусу тороїдальної форми [11]

$$
E_{M K}=\frac{1-\frac{m_{M K}}{m_{w}}}{\frac{m_{M K}}{m_{w}} C_{M K}},
$$

де $C_{M \kappa}-$ порівняльний коефіцієнт по вартості одиниці маси використаних матеріалів в корпусі (табл. 1).

Порівняння даних по вартості різних матеріалів (див. табл. 1) прийняті відносно вартості 1 кг сталі $\sigma_{0,2}=320$ МПа, оскільки вартість корпусних матеріалів з часом змінюється.

Для робочих глибин до 3000 м по вартості та співвідношенню $m_{M \kappa} / m_{w}$ при обмежені по міцності доцільно вибирати ВП на основі високоміцних вуглецевих волокон (ВП Е ЕП $=275-345$ ГПа).

Вартість намотаного тороїдального корпусу із ВП на основі середніх по модулю високоміцних волокон в 2,3 рази більше вартості корпусу зі СП. Але зі збільшенням робочої глибини занурення без збільшення модуля пружності скловолокна використання СП неефективне через необхідність збільшення товщини оболонки, а при товщині стінки намотаного виробу більше 80 мм важко забезпечити стабільність властивостей міцності готового виробу та технологію виготовлення. 
Порівняльні дані по вартості різних матеріалів за 1 кг по відношенню до сталі $\sigma_{0,2}=320$ МПа (2009-2011 рр.)

\begin{tabular}{|c|c|c|c|c|c|c|}
\hline \multirow[b]{2}{*}{$\begin{array}{c}\text { Порівняльний } \\
\text { коефіцієнт }\end{array}$} & \multicolumn{2}{|c|}{ Сталь } & \multirow{2}{*}{\begin{tabular}{|c} 
Титановий \\
сплав \\
$\sigma_{0,2}=$ \\
$600-800$ \\
МПа \\
\end{tabular}} & \multirow[b]{2}{*}{$\begin{array}{c}\text { СП із } \\
\text { високоміцного } \\
\text { скловолокна }\end{array}$} & \multicolumn{2}{|c|}{ ВП } \\
\hline & $\begin{array}{c}\sigma_{0,2}= \\
320 \mathrm{MПа}\end{array}$ & $\begin{array}{c}\sigma_{0,2}= \\
800-900 \\
\text { МПа }\end{array}$ & & & $\begin{array}{c}\mathrm{E}_{\mathrm{B \Pi}}= \\
600-965 \\
\Gamma \Pi \mathrm{a}\end{array}$ & $\begin{array}{c}\mathrm{E}_{\mathrm{B \Pi}}= \\
275-345 \\
\Gamma \Pi \mathrm{a}\end{array}$ \\
\hline $\mathrm{C}_{\mathrm{MK}}$ & 1 & 9,8 & $\approx 50$ & 9,2 & 794 & 24,3 \\
\hline
\end{tabular}

Вибір армуючого матеріалу, що забезпечує мінімальну масу та максимум несучої здатності корпусу, є достатньо неоднозначною задачею. При проектуванні тороїдальних міцних корпусів для підводної техніки слід звертати увагу на узгоджене підвищення як міцності, так i жорсткості односпрямованого ПКМ.

Порівняння ефективності різних матеріалів при обмежені по міцності дозволяють зробити однозначний вибір в сторону того або іншого матеріалу в якості конструкційного для міцного корпусу тороїдальної форми на попередньому етапі проектування.

Для оцінки ефективності МК, отриманого іншими схемами намотування, відповідно до запропонованого в роботі алгоритму необхідно проводити повний аналіз впливу всього простору параметрів проектування - геометрії тору, типу структури та типу компонентів ПКМ з урахуванням конструктивно-технологічних обмежень при виготовлені тороїдального МК способом намотування, що дозволить сформувати раціональну структуру стінки корпусу із ПКМ для забезпечення його максимальної несучої здатності та мінімуму маси.

Виготовлення міцного корпусу тороїдальної форми способом намотування із ПКМ з високою питомою міцністю та жорсткістю дозволить зменшити його масу і вартість, та збільшити корисне навантаження підводного апарату.

\section{Висновки}

1. Удосконалено метод розрахунку напружено-деформованого стану і оцінки міцності корпусу підводного апарату тороїдальної форми при гідростатичному стисканні шляхом врахування конструктивнотехнологічних факторів виготовлення способом намотування та практичних рекомендацій класифікаційного товариства Bureau Veritas.

2. Збільшення кількості поперечних шарів по відношенню до повздовжніх в 2 рази призводить до зменшення величини напружень $\sigma_{\theta}$ на $14 \%$ для ВП та на $12,6 \%$ для СП. 
3. Заміна розрахунку тороїдальної оболонки 3 шарами змінної товщини на оболонку з осередненою товщиною шарів уздовж поперечного перерізу призводить до зниження максимальних напружень $\sigma_{\theta}$ на $8 \%$ по зовнішній поверхні, та на $13 \%$ по внутрішній поверхні. Максимальні напруження $\sigma_{\theta}$ для обох методів знаходяться на внутрішній поверхні тороїдальної оболонки. Небезпечні точки при змінній товщині знаходяться в районі кутів $\theta=\pi / 6$ та $\theta=5 \pi / 6$, при осередненій товщині в районі кута $\theta=5 \pi / 6$.

4. При використанні удосконаленого методу величини напружень будуть максимальними на внутрішній поверхні, а для спрощеного методу на основі рішення Фепля вони будуть однакові для обох поверхонь. Так в при $\theta=0 \sigma_{\theta}$ в першому випадку вища на $30 \%$, при $\theta=\pi / 2$ вища на $37 \%$, при $\theta=\pi$ вища на $27 \%$, а для $\sigma_{\psi}$ при при $\theta=0$ вища на $52 \%$, при $\theta=\pi / 2$ вища на $36 \%$, при $\theta=\pi$ нижча на $22 \%$. Така велика розбіжність призводить до виникнення помилки в небезпечну сторону.

5. В розрахунку монолітних міцних корпусів зі СП та ВП на малих глибинах (до 1750 м) визначальним є позиція стійкості, а для великих глибин - позиція міцності. Для розрахунку традиційних матеріалів, в даному прикладі, визначальним $€$ позиція стійкості.

6. Економічна оцінка показала, що вартість намотаного тороїдального корпусу із ВП на основі середніх по модулю високоміцних волокон в 2,3 рази більше вартості корпусу зі СП. Але зі збільшенням робочої глибини занурення без збільшення модуля пружності скловолокна використання СП неефективне через необхідність збільшення товщини оболонки, а при товщині стінки намотаного виробу більше 80 мм важко забезпечити стабільність властивостей міцності готового виробу та технологію виготовлення.

\section{СПИСОК ЛІТЕРАТУРИ}

1. Бурдун Е.Т. Порівняння методів оцінки ефективних пружних характеристик тороїдального міџного корпусу підводного засобу виконаного намотуванням волокном / Е.Т. Бурдун, С.Ф.Присташ, С.П. Гейко, С.В. Копійка // Інноваиії в суднобудуванні та океанотехніці: матеріали VIII міжнародної науково-технічної конференції (Миколаїв, 26-28 вересня 2019 р.). Миколаїв: НУК, 2019 р. С. 239-243.

2. Sizonenko, $O$. Peculiarities of stress-strain state of toroidal pressure hull, made by winding / O. Sizonenko, E. Burdun, S. Prystash // International journal for science, technics and innovations for the industry. Machines, Technologies, Materials, Year XII Issue 6/2018. P. 240-243. 
3. Sizonenko, O. Peculiarities of stress-strain state of toroidal pressure hull, made by spiral winding / O. Sizonenko, E. Burdun, S. Prystash //International journal for science, technics and innovations for the industry. Machines, Technologies, Materials, PRINT ISSN 1313-0226, ISSN WEB 1314-507X, Year XII, Issue 11/2018. P. 466-469.

4. Присташ С.Ф. Метод розрахунку міцного корпусу підводного апарату в формі тору, виконаного намотуванням / С.Ф. Присташ, С.Т. Бурдун // Вісник Одеського національного морського університету. Одеса, 2017. № 4 (53). С. 152-163.

5. Гребенюк С.Н. Напряженно-деформированное состояние тороидальных оболочек / С.Н. Гребенюк, Ю.А. Сысоев, Ю.Н. Сысоев // Вісник Запорізького наиіонального університету 2010, № 2. C. 24-28.

6. Амбариумян С.А. Общая теория анизотропных оболочек / С.А. Амбариумян. М.: Изд-во НАУКА, 1974. 448 с. Bureau Veritas.: Hull in Composite Materials and Plywood, Material Approval, Design Principles, Construction and Survey. March 2012 / Rule Note NR 546 DT R00 E http://www.veristar.com/ portal/veristarinfo/detail? content-id=/repository/collaboration/ sites\%20content/live/veristarinfo/vi-content-avigation/generalinfo/ giRulesRegulations/bvRules/yachtsrules)

7. Burdun, Y.T. Rational designing of composite toroidal pressure hull for ocean engineering / Y.T. Burdun, A.V. Kreptiuk // Bестник Астраханского государственного технического университета. Серия: Морская техника и технология. Астрахань: АГТУ, 2014. № 2 (май). C. 27-36.

8. Корн Г. Справочник по математике для научных работников и инженеров / Г. Корн, Т. Корн. М.: Наука, 1968. 720 с.

9. Крептюк А.В. Проектирование и метод расчета устойчивости композитных тороидальных прочных корпусов подводных технических средств, полученных продольно-поперечной намоткой/ [Текст] А.В. Крептюк // Проблемы техники: Научно-производственный журнал. 2011.№ 2. С. 113-127.

10. Греков В.М. оченка технико-экономической эффективности применения высокпрочных материалов для корпусов подводной техники / В.М. Греков, Б.В. Дружсиловский, В.М. Рябов // Труды ЦНИИ им. акад. А.Н. Крылова. СПб.: ЦНИИ им. акад. Крыллова, 2010. №56 (340). С. 187-194. 


\section{REFERENCES}

1. Burdun, E.T. Prystash, S.F., Heiko, S.P., Kopiika, S.V. (2019). Porivniannia metodiv otsinky efektyvnykh pruzhnykh kharakterystyk toroidalnoho mitsnoho korpusu pidvodnoho zasobu vykonanoho namotuvanniam voloknom Innovatsii v sudnobuduvanni ta okeanotekhnitsi: materialy VIII mizhnarodnoi naukovo-tekhnichnoi konferentsii. Mykolaiv: NUK, 2019 r. P. 239-243 (in Russian).

2. Sizonenko, O., Burdun, E., Prystash, S. (2018) Peculiarities of stress-strain state of toroidal pressure hull, made by winding. International journal for science, technics and innovations for the industry. Machines, Technologies, Materials, Year XII Issue 6, pp. 240-243.

3. Sizonenko, O., Burdun, E., Prystash, S. (2018) Peculiarities of stress-strain state of toroidal pressure hull, made by spiral winding. International journal for science, technics and innovations for the industry. Machines, Technologies, Materials, PRINT ISSN 1313-0226, ISSN WEB 1314-507X, Year XII, Issue 11, pp. 466-469.

4. Prystash, S.F., Burdun, Ye.T. (2017.) Metod rozrakhunku mitsnoho korpusu pidvodnoho aparatu $v$ formi toru, vykonanoho namotuvanniam. Visnyk Odeskoho natsionalnoho morskoho universytetu. Odesa, № 4 (53). pp. 152-163. (in Russian).

5. Hrebeniuk, S.N., Sysoev, Yu.A., Sysoev, Yu.N (2010) Napriazhenno-deformyrovannoe sostoianye toroydalnblkh obolochek. Visnyk Zaporizkoho natsionalnoho universytetu, № 2. P. 24-28. (in Russian).

6. Ambarcumjan, S.A. (1974) Obshhaja teorija anizotropnyh obolochek/S.A. Ambarcumjan. Moskva: NAUKA, 448 p. (in Russian).

7. Bureau Veritas: Hull in Composite Materials and Plywood, Material Approval, Design Principles, Construction and Survey. March 2012 / Rule Note NR 546 DT R00 E http://www. veristar. com/ portal/veristarinfo/detail?content-id=/repository/collaboration/ sites\%20content/live/veristarinfo/vi-content-avigation/generalinfo/giRulesRegulations/bvRules/yachtsrules).

8. Burdun, Y.T. Kreptiuk, A.V. (2014) Rational designing of composite toroidal pressure hull for ocean engineering. Vestnyk Astrakhanskoho hosudarstvennoho tekhnycheskoho unyversyteta. Seryia: Morskaia tekhnyka y tekhnolohyia. Astrakhan: AHTU. № 2. P. 27-36. (in Russian). 
ВІСНИК

ОДЕСЬКОГО НАЦІОНАЛЬНОГО

МОРСЬКОГО УНІВЕРСИТЕТУ

№ 2 (62), 2020
HERALD

OF THE ODESSA NATIONAL

MARITIME UNIVERSITY

№ 2 (62), 2020

9. Korn, G. Korn, T. (1968) Spravochnik po matematike dlja nauchnyh rabotnikov i inzhenerov. M.: Nauka, 720 p. (in Russian).

10. Grekov, V.M., Druzhilovskij, B.V., Rjabov, V.M. (2010) Ocenka tehniko-jekonomicheskoj jeffektivnosti primenenija vysokprochnyh materialov dlja korpusov podvodnoj tehniki. Trudy CNII im. akad. A.N. Krylova. Sankt-Peterburg: CNII im. akad. Krylova, № 56 (340). P. 187-194. (in Russian).

Стаття надійшла до редакиії 10.03.2020

Посилання на статтю: Бурдун Є.Т., Присташ С.Ф. Удосконалення методу розрахунку міцності корпусу підводного апарату тороїдальної форми, виготовленого намотуванням // Вісник Одеського національного морського університету: Зб. наук. праць, 2020. № 2 (62). C. 90-105. DOI 10.47049/ 2226-18932020-2-90-105.

Article received 10.03.2020

Reference a JournalArtic: Burdun, E., Prystash, S. Improvement of the method of calculation of strength of the pressure hull of the underwater apparatus of the toroidal form, made by winding. // Herald of the Odessa national maritime university. 2020. 2(62), 90-105. DOI 10.47049/2226-1893-2020-2-90-105. 